\title{
Interdependence of domestic malaria prevention measures and mosquito-human interactions in urban Dar es Salaam, Tanzania
} Yvonne Geissbühler*1,2, Prosper Chaki²,3,5, Basiliana Emidi 3,4, Nicodemus J Govella2,3,5, Rudolf Shirima ${ }^{3}$, Valeliana Mayagaya ${ }^{2}$, Deo Mtasiwa ${ }^{3}$, Hassan Mshinda ${ }^{2}$, Ulrike Fillinger ${ }^{5}$, Steven W Lindsay ${ }^{5}$, Khadija Kannady ${ }^{3}$, Marcia Caldas de Castro $^{6}$, Marcel Tanner ${ }^{1}$ and Gerry F Killeen 1,2,5

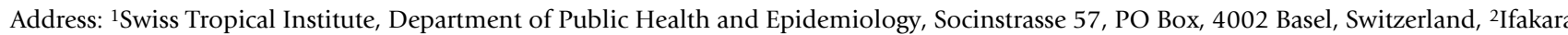 \\ Health Research and Development Centre, Co-ordination Office, Kiko Avenue, PO Box 78373, Dar es Salaam, Tanzania, ${ }^{3}$ Dar es Salaam City \\ Council, Dar es Salaam, Tanzania, ${ }^{4}$ University of Dar es Salaam, Dar es Salaam, Tanzania, 5 School of Biological and Biomedical Sciences, South \\ Road, Durham DH1 3LE, UK and ${ }^{6}$ Department of Population and International Health, Harvard School of Public Health, 655 Huntington Avenue, \\ Boston, MA 02115, USA \\ Email: Yvonne Geissbühler* - Y.Geissbuehler@unibas.ch; Prosper Chaki - pchaki@ihrdc.or.tz; Basiliana Emidi - ebasi2002@yahoo.co.uk; \\ Nicodemus J Govella - govella@ihrdc.or.tz; Rudolf Shirima - rruffinis@yahoo.com; Valeliana Mayagaya - vmayagaya@ihrdc.or.tz; \\ Deo Mtasiwa - rcmoh@raha.com; Hassan Mshinda - hmshinda@ihrdc.or.tz; Ulrike Fillinger - ulrike.fillinger@durham.ac.uk; \\ Steven W Lindsay - s.w.lindsay@durham.ac.uk; Khadija Kannady - kadkhadija@yahoo.co.uk; Marcia Caldas de \\ Castro - mcastro@hsph.harvard.edu; Marcel Tanner - Marcel.Tanner@unibas.ch; Gerry F Killeen - gkilleen@ihrdc.or.tz \\ * Corresponding author
}

Published: 19 September 2007

Malaria Journal 2007, 6:126 doi:10.1186/1475-2875-6-126

This article is available from: http://www.malariajournal.com/content/6/1/126

(c) 2007 Geissbühler et al; licensee BioMed Central Ltd.

This is an Open Access article distributed under the terms of the Creative Commons Attribution License (http://creativecommons.org/licenses/by/2.0), which permits unrestricted use, distribution, and reproduction in any medium, provided the original work is properly cited.

\begin{abstract}
Background: Successful malaria vector control depends on understanding behavioural interactions between mosquitoes and humans, which are highly setting-specific and may have characteristic features in urban environments. Here mosquito biting patterns in Dar es Salaam, Tanzania are examined and the protection against exposure to malaria transmission that is afforded to residents by using an insecticide-treated net (ITN) is estimated.
\end{abstract}

Methods: Mosquito biting activity over the course of the night was estimated by human landing catch in 216 houses and I,064 residents were interviewed to determine usage of protection measures and the proportion of each hour of the night spent sleeping indoors, awake indoors, and outdoors.

Results: Hourly variations in biting activity by members of the Anopheles gambiae complex were consistent with classical reports but the proportion of these vectors caught outdoors in Dar es Salaam was almost double that of rural Tanzania. Overall, ITNs confer less protection against exophagic vectors in Dar es Salaam than in rural southern Tanzania $(59 \%$ versus $70 \%$ ). More alarmingly, a biting activity maximum that precedes $10 \mathrm{pm}$ and much lower levels of ITN protection against exposure (38\%) were observed for Anopheles arabiensis, a vector of modest importance locally, but which predominates transmission in large parts of Africa.

Conclusion: In a situation of changing mosquito and human behaviour, ITNs may confer lower, but still useful, levels of personal protection which can be complemented by communal transmission suppression at high coverage. Mosquitoproofing houses appeared to be the intervention of choice amongst residents and further options for preventing outdoor transmission include larviciding and environmental management. 


\section{Background}

Malaria and other vector borne diseases are major contributors to the global burden of disease and a significant impediment to socioeconomic development in poor countries [1]. It is estimated that 300 to 660 million clinical attacks of malaria occur globally [2] which result in at least 1 million deaths [3,4]. Over $80 \%$ of these deaths occur in Africa [4]. Approximately $70 \%$ of clinical malaria attacks occur in sub-Saharan Africa with the vast bulk of the remainder occurring in south East Asia [4]. Sub-Saharan Africa has the highest incidence because ideal climatic conditions for transmission are exacerbated by some of the world's most efficient malaria vectors, such as Anopheles gambiae, Anopheles arabiensis and Anopheles funestus [5].

While the bulk of malaria research in Africa has focused on rural areas, the growing importance of urban settings is increasingly recognized [6-11]. Transmission intensity is generally lower in urban areas but it is estimated that, by the year 2030, more than $50 \%$ of the African population will live in towns and cities [12] so improved understanding and evidence-based strategies for controlling urban malaria are needed. Urban areas differ from rural settings in that exposure to transmission is typically lower and access to diagnosis, treatment and preventative measures is much better [6-11]. As recently elucidated using detailed transmission models [13-15], such lower exposure levels lead to a lower level of immunity in the population as a whole, as well as to higher prevalence, morbidity, mortality and infectiousness in older age groups [6-10,16]. Furthermore, the distribution of seasonal and permanent breeding sites is highly localized, leading to patchy, heterogeneous transmission at particularly fine spatial scales [7,17-21]. Malaria prevalence and incidence tends to be much higher for residents living close to major larval habitats [19,22-24]. This is because mosquitoes tend not to disperse far from the breeding sites as blood meal and aquatic habitat resources are in close proximity to each other [19,25-27]. This may even be true for water bodies which are not suitable for larval development but do act as oviposition sites [28], possibly resulting in the proportion of infectious mosquitoes increasing with the distance from their location of actual emergence [29]. Urban settings often have large areas with relatively good housing and relatively high coverage with personal protection measures such as ITNs, repellents and coils [11,30-35] with the potential to force changes in epidemiologically relevant behavioural patterns of vector mosquitoes [36-49].

Anopheles gambiae and its sibling species An. arabiensis are the most important vectors of malaria in most parts of Africa, where they readily adapt to urban ecosystems by ovipositing and developing in atypical larval habitats such as domestic containers and polluted water bodies [50-52].
Although these species are most commonly found in artificial larval habitats, even in rural areas, this is particularly the case in towns and cities [51-57]. Despite the enormous importance of these mosquito species, relatively little is known about their feeding behaviour, and even less about their broader ecology, particularly in urban setting. Furthermore, the influence of insecticide-treated nets (ITNs) [4,58,59], improved housing [60,61] and other personal protection [62-65] methods upon their feeding behaviour has been discussed qualitatively but has yet to be evaluated in quantitative terms. There is one example of Zimbabwe, where after eight years of insecticide spraying more An. gambiae sensu lato (s.l.) (as sibling species within this complex were not resolved in that study) were caught biting outdoors than indoors whereas before the intervention there was no difference $[66,67]$. In many places throughout Africa, a reduced indoor biting was reported due to ITNs and impregnated curtains [37,39,42,45,46,68-71] through a combination of increased mosquito mortality caused by their insecticidal properties and the reduction of mosquito house entry caused by their excito-repellent properties [49,72,73]. Indoor biting rates of malaria vectors can be reduced by improved housing, specifically mosquito-proof screening, closed eaves, ceilings and sealed frames for windows and doors [19,60,61,74-78] and some recent studies suggest changes in their biting patterns in response to personal or household protection measures $[36,79,80]$. However, only $20 \%(4 / 20)$ of the studies described in these papers have been carried out in urban areas so here the behavioural interactions between vector mosquitoes and their human hosts in the context of a large-scale integrated malaria control programme in Dar es Salaam, Tanzania are examined $[52,81]$.

In Dar es Salaam, the main malaria vectors are members of the An. gambiae species complex and An. funestus [82]. Dar es Salaam has a relatively high coverage with bednets and ITNs (91.8\% and 43.1\%, respectively) [33]. In order to see if increasing ITN usage and house quality has influenced mosquito biting behaviour, a survey of behavioural interactions between mosquitoes and humans during the main rains of 2006 was undertaken. This study was also carried out in order to estimate the extent of protection against exposure to malaria transmission that is afforded to residents of Dar es Salaam by using an ITN and to evaluate the influence of housing quality upon this level of protection. Furthermore, the implication these behaviours have for malaria control in Dar es Salaam and elsewhere in Africa where similar trends are observed are discussed. 


\section{Methods Study site}

Dar es Salaam is situated at the shores of the Indian Ocean coast with a hot and humid climate which is ideal for mosquito proliferation and malaria transmission, satisfying the climatic requirement for stable transmission of temperatures between $22^{\circ} \mathrm{C}$ and $32^{\circ} \mathrm{C}$ and a rainfall of around $80 \mathrm{~mm}$ per month for at least five months per year [83]. There are typically two rainy seasons: a main rainy season from March to June and a shorter, more erratic rainy season from October to December. Dar es Salaam has around 2.5 million inhabitants and covers a total area of $1,400 \mathrm{~km}^{2}$ [84]. The city is divided into three municipalities; Temeke, Ilala and Kinondoni which collectively comprise 73 wards. Each ward is further subdivided into neighbourhoods known as mitaa (singular mtaa) which typically comprise between 20 and 100 mashina (singular shina) or Ten Cell Units (TCU). The TCU is the smallest subunit of local government in Tanzania which, in principle, comprises a cluster of 10 houses with an elected representative known as a mjumbe although in practice most TCUs include 20-30 houses and some may even exceed 100. This study was based within the project area of the ongoing Urban Malaria Control Programme (UMCP) implemented by the Dar es Salaam City Council [52,81]. The main project area includes five wards from each municipality with a total of 67 mitaa. Overall, this study area covers an area of $55 \mathrm{~km}^{2}$ with a total population of 609,514 people [84]. The houses surveyed here were located in five wards, eight mitaa (Figure 1).

For comparison, the results obtained in Dar es Salaam are contrasted with those obtained with similar methodology in the Kilombero Valley, a rural setting with intense perennial malaria transmission in southern Tanzania [85].

\section{Preliminary survey of the overall study site}

For the purposes of routine monitoring and programme management, the UMCP surveys mosquito biting densities at 268 locations (four in each $\mathrm{mtaa}$ ), distributed across the study area every four weeks. Initial trials proved that existing trapping technologies were not sufficiently sensitive to monitor the low densities of An. gambiae which occur across the study area. Therefore, outdoor human landing catch (HLC) [86] has been implemented as the standard sampling tool for adult mosquitoes as an interim measure until a suitable alternative is proven practical, effective and affordable. Once every four weeks at each location, HLC is conducted from $6 \mathrm{pm}$ to 6 am for 45 minutes of each hour, allowing 15 minute breaks for rest, hot drinks and snacks. All collected mosquitoes are identified morphologically to genus and, in the case of Anopheles to species complex level $[87,88]$. Members of the Anopheles gambiae species complex are further resolved to sibling species level by polymerase chain reaction (PCR)
[89]. The sporozoite infection status of each mosquito was determined by enzyme-linked immunoabsorbent assay as previously described [90].

HLCs between April and December 2005 were used to identify the primary vectors of malaria in Dar es Salaam and to test for variation by location in the distribution of An. gambiae biting activity across the night. Members of the An. gambiae species complex were identified as the major malaria vectors in Dar es Salaam (See Results) so only these species were considered in the following analysis and study design. The influence of location as a determinant of An. gambiae biting habits was tested by treating TCU unique ID for each sampled site as a fixed factor in a logistic model with the proportion of mosquitoes caught during typical sleeping hours of city residents $(10 \mathrm{pm}$ to 6 am; see results) as the outcome variable. This data set was also used to identify sites with the highest densities of $A n$. gambiae s.l. for the detailed and intensive mosquito behavioural surveys described below.

\section{Detailed surveys of mosquito biting behaviour}

The 12 TCU in Temeke municipality and 2 TCU in Ilala municipality, which had the highest An. gambiae s.l. densities in the UMCP surveillance system, were selected for further, more detailed, surveys of the behavioural patterns of mosquitoes and humans. Informed consent was obtained from 216 houses in order to conduct HLC both indoors and outdoors. In each house, HLC was conducted for one night from $6 \mathrm{pm}$ to $7 \mathrm{am}$ as described above except that catchers switched between indoor and outdoor stations every hour in order to preclude biases resulting from variations in individual attractiveness [91-93]. These human landing catch surveys took place during 10 weeks of the main rainy season between April and June 2006. In order to estimate the biting rate for a full hour, total catches per hour were divided by 0.75 .

\section{Interview surveys of human behaviour and domestic protection measures}

A brief interview was conducted with all household members present at the time of the interview. They were asked where they usually eat dinner, where they stay after dinner before going to bed, what time they go to bed and what time they typically get out of bed in the morning. Furthermore, they were asked which preventive measures, such as bednets or insecticides, they use to avoid mosquito bites. The quality of their houses, i.e. the quality of screening and availability of ceiling boards was examined in each household. In order to verify the sleeping and resting behaviours reported by residents during interviews, also surveys were conducted based on direct observation by walking through these TCUs once every hour of the night and counting the number of people seen outdoors. Direct observation surveys were conducted for three nights in 


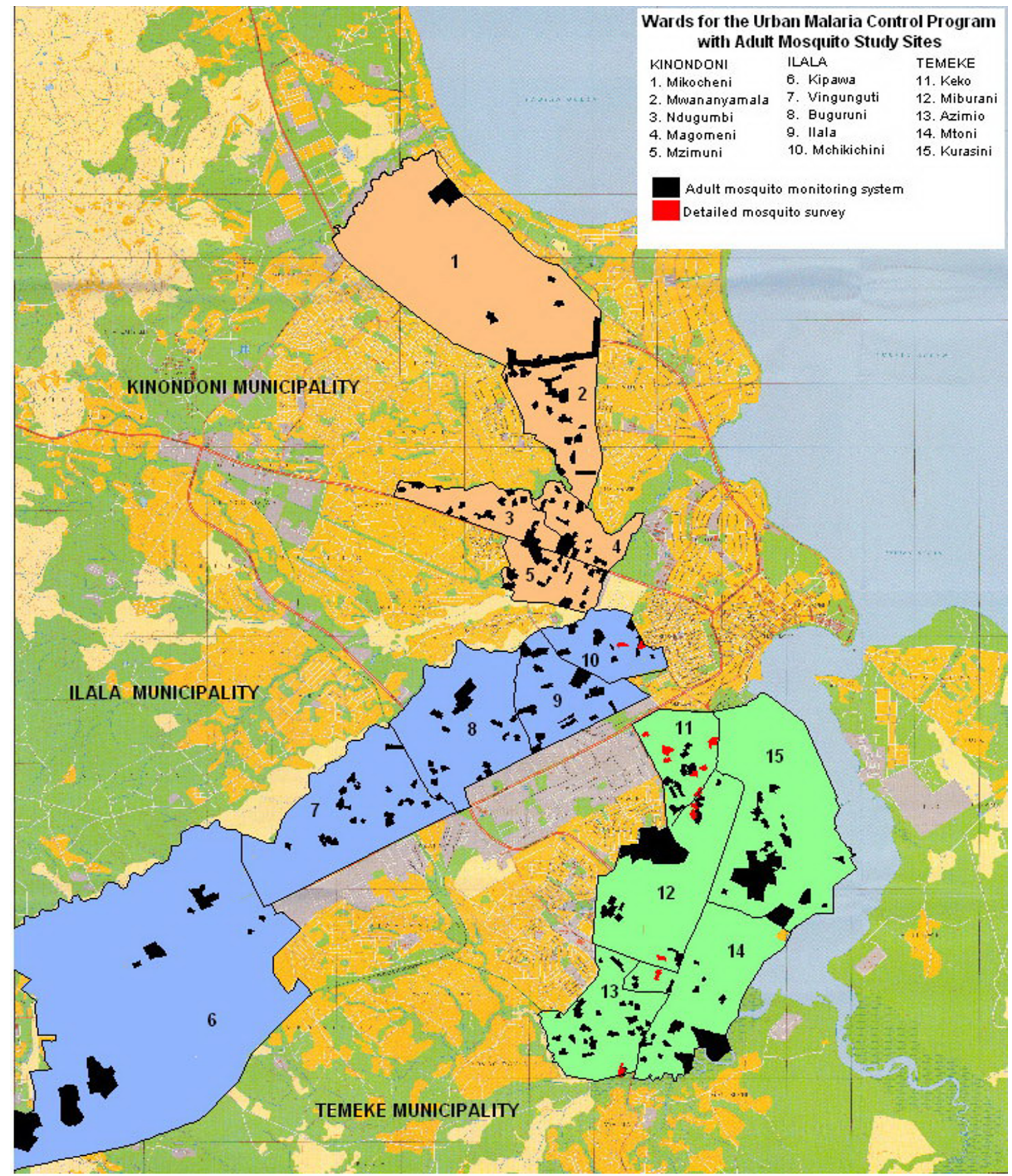

Figure I

Wards included in the study area of the Urban Malaria Control Program in Dar es Salaam, showing the ten cell units (TCU) of the adult mosquito monitoring system as well as of the detailed survey. 
each TCU. Once validated by direct observation (see results), the questionnaire reports were used to estimate proportion of the inhabitants in each of the three behavioural compartments (outdoor, indoor awake, indoor asleep) at each hour of the night.

\section{Estimating the protective efficacy of ITNs in terms of reduced biting exposure}

Data from the human and mosquito behavioural surveys described above were integrated to evaluate the interaction between them using an extension of a recently developed mathematical model [85]. EIR is the product of the biting rate experienced by humans exposed to a vector population and the sporozoite infection prevalence of that mosquito population [94]. The latter is only reduced by community-level impacts of malaria interventions $[95,96]$ so here personal protection purely in terms of biting rates and the impact that protective measures such as ITNs have upon them were estimated. First $\mathrm{B}_{\mathrm{u}, \mathrm{t}^{\prime}}$ the mean biting rate experienced by an unprotected individual at each time of the night $(\mathrm{t})$, based on the proportion of time spent outdoors multiplied by the outdoor biting rate at that time $\left(\mathrm{B}_{\mathrm{o}, \mathrm{t}}\right)$ plus the proportion of that hour spent indoors multiplied by the indoor biting rate at that time $\left(\mathrm{B}_{\mathrm{i}, \mathrm{t}}\right)$ was calculated. The main difference between this model and the one of Killeen et al. is that, because of the available information from the questionnaires, there was the possibility to divide the indoor compartment into being indoor but not asleep (and therefore not under a bednet) and being indoor and asleep (and, therefore, protected if using a bednet). The proportion of people sleeping or trying to sleep in bed and indoors $\left(S_{t}\right)$ is not the same as the proportion of people staying indoors asleep or not asleep $\left(\mathrm{I}_{\mathrm{t}}\right)$. If people are unprotected because they do not have a bednet, it only matters if they are indoors or outdoors and thus they experience the following biting rate:

$$
\mathrm{B}_{\mathrm{u}, \mathrm{t}}=\mathrm{B}_{\mathrm{o}, \mathrm{t}}\left(1-\mathrm{I}_{\mathrm{t}}\right)+\mathrm{B}_{\mathrm{i}, \mathrm{t}} \mathrm{I}_{\mathrm{t}}
$$

The number of bites experienced per night, or nightly biting rate, for an unprotected non-user $\left(B_{u}\right)$ can thus be calculated by summing the relevant biting rates for each hour:

$$
\mathrm{B}_{\mathrm{u}}=\sum_{\mathrm{t}=1}^{24} \mathrm{~B}_{\mathrm{u}, \mathrm{t}}
$$

Note that an unprotected individual is defined as someone lacking any net whereas a protected individual is defined as someone regularly using an effectively insecticidal net. The nightly biting rate of a protected individual $\left(B_{p}\right)$ based on the combined nightly profiles of mosquito biting rate $\left(B_{u, t}\right)$ over time $(t)$, the protective efficacy of ITNs (P), which is assumed to be constant, and the behav- iour of humans which results in fluctuating adherence of ITN users over the course of the night was modelled. As here a more detailed behavioural survey was taken into account, the nightly biting rate of a protected individual is calculated by multiplying the proportion of time spend outdoors at a certain time of the night by the outdoor biting rate at that time $\left(\mathrm{B}_{\mathrm{o}, \mathrm{t}}\right)$ plus the proportion of that hour being indoors but not asleep $\left(\mathrm{I}_{t}-\mathrm{S}_{\mathrm{t}}\right)$ multiplied by the indoor biting rate during that hour $\left(\mathrm{B}_{\mathrm{i}, \mathrm{t}}\right)$ plus the proportion of that time spent indoors being asleep under an ITN multiplied by the indoor biting rate at that hour $\left(\mathrm{B}_{\mathrm{i}, \mathrm{t}}\right)$ times the proportion of bites which can not be prevented by an ITN (1-P), as measured in experimental hut trials $[44,97,98]$. The effective adherence to ITN use at a given time of the night was assumed to be equivalent to the proportion of people sleeping at that time $\left(\mathrm{S}_{\mathrm{t}}\right)$. This assumption allows us to express the overall effect of this interaction as follows:

$B_{p}=\sum_{t=1}^{24} B_{p, t}=\sum_{t=1}^{24}\left[B_{o, t}\left(1-I_{t}\right)+B_{i, t}\left(I_{t}-S_{t}\right)+B_{i, t} S_{t}(1-P)\right]$

Based on existing evidence from experimental hut trials $[49,97,98]$, a conservative minimum protective efficacy level of $80 \%$ for ITNs $(P=0.8)$, equivalent to a relative exposure to bites of $20 \%$ when, and only when, actually sleeping under the net, was assumed. In this study, it was possible to take into account the proportion of people staying indoors or outdoors during waking hours and experiencing the corresponding biting rate. Furthermore, there was the possibility even to do the same for people living in different house quality who spent different amount of time in different compartments. During sleeping hours, people staying indoors were presumed sleeping under an ITN if available, whereas people sleeping outdoors were presumed not using a net and being fully exposed to the outdoor biting rate.

Taking the data for nightly human and mosquito behaviour profiles, the relative biting rate for ITN users which is equivalent to relative availability of protected individuals $\left(\lambda_{\mathrm{p}}\right)$ as previously defined (See equations 8 and 14 in reference [95]), could be estimated. $\lambda_{p}$ was calculated by comparing the total biting rate that protected individuals are exposed to $\left(B_{p}\right)$ with that of non-users $\left(B_{u}\right)$ who are unprotected:

$$
\lambda_{\mathrm{p}}=\mathrm{B}_{\mathrm{p}} / \mathrm{B}_{\mathrm{u}}
$$

The true protective efficacy of an ITN $\left(\mathrm{P}^{*}\right)$ against transmission exposure is then calculated as the overall nightly reduction of biting rate:

$$
\mathrm{P}^{*}=1-\lambda_{\mathrm{p}}
$$


This estimate of protective efficacy differs from that previously reported from experimental hut trials as well as previous applications of this approach [85], because it allows for typical shortcomings in adherence resulting from the time people typically spend outside of their ITN indoor, as well as outdoors and even considering people staying or sleeping the whole night outdoors. Note, however, that this estimate is merely a comparison between the biting rates experienced by those who use an ITN and those who do not. It does not include the community-level protection of both groups when ITNs reach sufficient levels of coverage to reduce vector biting densities and sporozoite prevalence over large areas [95].

Distinct and useful indicators with which to interpret the results of the above equations are the proportion of exposure which occur indoors and the proportion that occurs during sleeping hours. The proportion of bites that occur during the observed peak sleeping hours $\left(\pi_{\mathrm{s}}\right)$ for an unprotected individual can thus be calculated as the nightly biting rate experienced during these hours divided by the total nightly biting rate:

$$
\pi_{\mathrm{s}}=\sum_{\mathrm{t}=10 \mathrm{pm}}^{6 \mathrm{am}} \mathrm{B}_{\mathrm{u}, \mathrm{t}} / \sum_{\mathrm{t}=1}^{24} \mathrm{~B}_{\mathrm{u}, \mathrm{t}}
$$

Note that $\pi_{\mathrm{s}}$ describes the proportion of human exposure during which an ITN is in use and is used as a key parameter for modelling the community- and individual-level effects of ITNs upon malaria transmission [95]. Overall, $\pi_{\mathrm{s}}$ was usually calculated using median reported values of 10 $\mathrm{pm}$ to 6 am for the whole study area but was evaluated separately for individual houses or houses with different quality of screening and ceiling boards for some analysis.

The proportion of bites occurring indoors but while awake and, therefore, not protected by a bednet $\left(\pi_{\mathrm{a}}\right)$ can be calculated as the estimated number of bites estimated to occur indoors while awake, divided by the total number of bites estimated to occur both indoors and outdoors:

$$
\pi_{\mathrm{a}}=\sum_{\mathrm{t}=1}^{24}\left[\mathrm{~B}_{\mathrm{i}, \mathrm{t}}\left(\mathrm{I}_{\mathrm{t}}-\mathrm{S}_{\mathrm{t}}\right)\right] / \sum_{\mathrm{t}=1}^{24}\left[\mathrm{~B}_{\mathrm{o}, \mathrm{t}}\left(1-\mathrm{I}_{\mathrm{t}}\right)+\mathrm{B}_{\mathrm{i}, \mathrm{t}} \mathrm{I}_{\mathrm{t}}\right]
$$

The proportion of bites occurring indoors $\left(\pi_{\mathrm{i}}\right)$ for an unprotected individual can be calculated as the total number of bites estimated to occur indoors, divided by the total number of bites estimated to occur both indoors and outdoors. It should be noted that this equivalent to summing $\pi_{\mathrm{a}}$ and $\pi_{\mathrm{s}}$ :

$$
\pi_{\mathrm{i}}=\pi_{\mathrm{a}}+\pi_{\mathrm{s}}=\sum_{\mathrm{t}=1}^{24}\left[\mathrm{~B}_{\mathrm{i}, \mathrm{t}} \mathrm{I}_{\mathrm{t}}\right] / \sum_{\mathrm{t}=1}^{24}\left[\mathrm{~B}_{\mathrm{O}, \mathrm{t}}\left(1-\mathrm{I}_{\mathrm{t}}\right)+\mathrm{B}_{\mathrm{i}, \mathrm{t}} \mathrm{I}_{\mathrm{t}}\right]
$$

\section{Ethical considerations}

All activities of the UMCP, including these field surveys are approved by the Medical Research Coordination Committee of the National Institute for Medical Research, Ministry of Health, Government of Tanzania (Reference numbers NIMR/HQ/R.8a/Vol. IX/279 and 324). No persons in high risk groups, namely people under 18 years or women of reproductive age, were recruited to conduct human landing catches. Furthermore, the human landing catchers were screened every week for malaria microscopic examination of thick smear peripheral blood samples and treated with artemisinin-based combination therapy when diagnosis was positive.

\section{Results and Discussion \\ Preliminary surveys of the entire study area}

In the areas in Dar es Salaam which were covered by the urban malaria control programme (UMCP) during the first three rounds of the household surveys, bed net usage was quite high and mosquito-proofed houses were common with many being made of concrete or bricks with a corrugated iron roof (Table 1). Around half of the houses had a complete ceiling board and/or good screening although a small proportion of residents didn't use any protection measures at all. The same was true in the TCUs which were selected for the more detailed study (Table 2). When compared to historical reports from Dar es Salaam, bednet usage had increased whereas the use of other protective measures had decreased [34]. In contrast, in the Kilombero Valley in southern Tanzania, where ITNs have been promoted since 1997, bednet use is currently approximately at the same level, but both treatment of these nets and the use of other protective measures (coil, spray or repellent) are higher in Dar es Salaam (Killeen et al, Unpublished). Bed net usage in two contemporary Kenyan cities in 2001 was slightly lower and it should be noted that while screening of houses was less common than in Dar es Salaam, use of personal protection measures was more common [99].

A total of 1,388 An. gambiae s.l. (meaning members of the species complex as a whole in the absence of further identification to species by cytological or molecular methods) were caught in 1,650 catcher-nights, through routine monitoring activities of the UMCP during the preliminary survey of the entire study area (Figure 2). The majority of these proved to be An. gambiae (often referred to as $A n$. gambiae sensu stricto): $75.6 \%, 21.3 \%$ and $3.1 \%$ of 1099 successfully amplified specimens proved to be An. gambiae s.s., An. arabiensis and Anopheles merus, respectively. 
Table I: Characteristics of the houses and residents in all 15 wards of the study area in Dar es Salaam, Tanzania, during the first three rounds of household surveys from May 2004 until May 2006

\begin{tabular}{|c|c|c|}
\hline \multirow[t]{2}{*}{ Characteristic } & \multicolumn{2}{|c|}{ Frequency } \\
\hline & $N$ & $\%$ \\
\hline Houses & 3073 & 100 \\
\hline Walls & 3073 & 100 \\
\hline $\begin{array}{l}\text { Stone, cement, fired or } \\
\text { concrete bricks }\end{array}$ & 1684 & 54.4 \\
\hline $\begin{array}{l}\text { Unfired bricks, sand, } \\
\text { wood }\end{array}$ & 1355 & 43.7 \\
\hline $\begin{array}{l}\text { Corrugated iron sheets, } \\
\text { mud, grass }\end{array}$ & 59 & 1.9 \\
\hline $\begin{array}{l}\text { Grass thatch, } \\
\text { cardboard }\end{array}$ & 0 & 0 \\
\hline Roof & 3073 & 100 \\
\hline $\begin{array}{l}\text { Tiles, cement, } \\
\text { reinforced concrete }\end{array}$ & 193 & 6.3 \\
\hline $\begin{array}{l}\text { Corrugated iron sheets, } \\
\text { asbestos }\end{array}$ & 2868 & 93.3 \\
\hline $\begin{array}{l}\text { Thatch, sticks, mud, } \\
\text { grass, plastic sheets }\end{array}$ & 11 & 0.4 \\
\hline Ceiling board & 3066 & 100 \\
\hline Whole house & 829 & 27 \\
\hline Partly & 554 & 18.1 \\
\hline None & 1683 & 54.9 \\
\hline Screening & 3057 & 100 \\
\hline Intact & 684 & 22.4 \\
\hline With holes & 1006 & 32.9 \\
\hline Incomplete & 503 & 16.5 \\
\hline Glass windows & 105 & 3.4 \\
\hline None & 759 & 24.8 \\
\hline Residents & 20289 & 100 \\
\hline Bednet coverage & 20285 & 100 \\
\hline User & 16883 & 83.2 \\
\hline Non-user & 3402 & 16.8 \\
\hline Treatment status of net & 16883 & 100 \\
\hline $\begin{array}{l}\text { Treated in last } 6 \\
\text { months }\end{array}$ & 5194 & 30.8 \\
\hline $\begin{array}{l}\text { Treated more than } 6 \\
\text { months ago }\end{array}$ & 66 & 0.4 \\
\hline Never treated & 11623 & 68.8 \\
\hline $\begin{array}{l}\text { Other protection against } \\
\text { mosquitoes }\end{array}$ & 20287 & 100 \\
\hline Coil & 1245 & 6.1 \\
\hline Spray & 2167 & 10.7 \\
\hline Repellent & 307 & 1.5 \\
\hline None & |657| & 81.7 \\
\hline $\begin{array}{l}\text { Usage of at least I } \\
\text { protection measure }\end{array}$ & 20289 & 100 \\
\hline $\begin{array}{l}\text { Net, coil, spray, } \\
\text { repellent }\end{array}$ & 17437 & 85.9 \\
\hline None & 2852 & 14.1 \\
\hline
\end{tabular}

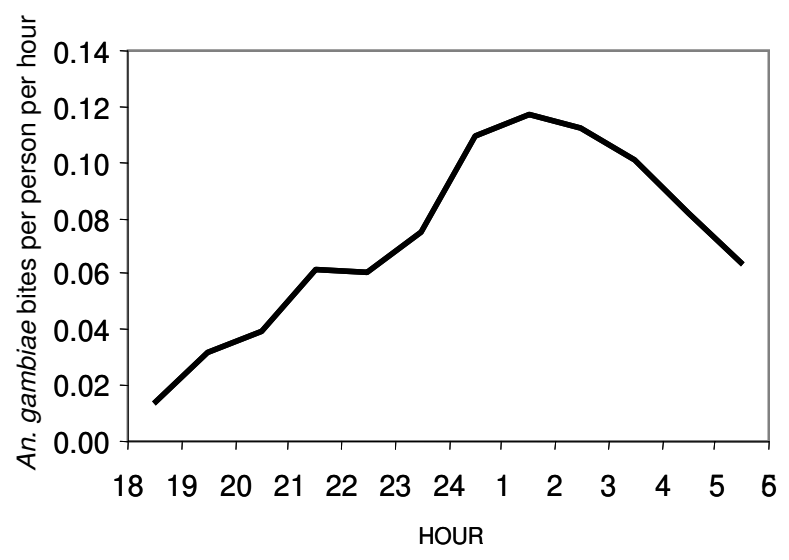

Figure 2

Hourly biting profile of An. gambiae s.l. based on averaged results of routine outdoor human landing catches from across the entire study area covered by the Urban Malaria Control Programme.

During the same preliminary surveys, only 55 An. funestus were caught, indicating that although it is usually a very efficient vector [87], its contribution to transmission in urban Dar es Salaam is minor. Nevertheless, sporozoite infection and local transmission within urban Dar es Salaam was confirmed for An. gambiae s.s. $(0.24 \% ; 2 / 831)$ and An. funestus $(2.32 \%, 1 / 43)$, but not $A n$. arabiensis $(0.0 \%, 0 / 234)$ and $A n$. merus $(0.0 \%, 0 / 34)$. Estimates of actual transmission intensity and its spatio-temporal heterogeneity over longer, more representative time periods will be reported in detail elsewhere. The only other Anopheles species caught was Anopheles coustani (370), of which none were found to be sporozoite-infected, so it is thought to contribute little or no vectorial capacity as described elsewhere [87].

Anopheles gambiae s.s. was by far the most important vector in the study area so all subsequent analysis focus upon this species and, to a lesser extent, An. arabiensis. Based on preliminary surveys of the total study area, location had no influence upon the proportion of An. gambiae s.l. bites which occurred between $10 \mathrm{pm}$ and 6 am when residents of Dar es Salaam typically slept (An. gambiae s.s.: P = 0.519 by logistic regression, $\mathrm{N}=72$ locations, $\mathrm{n}=714$ mosquitoes, An. arabiensis: $\mathrm{P}=0.398$ by logistic regression, $\mathrm{N}=32$ locations, $\mathrm{n}=133$ mosquitoes). The great majority of the combined bites of these species occurred during sleeping hours $\left(\pi_{\mathrm{s}}=83.16 \%\right.$; equation 6$)$. Subsequent detailed surveys of mosquito and human behaviours therefore focussed upon the 14 TCUs with the highest An. gambiae densities observed during the preliminary site-wide surveys (Figure 1). 

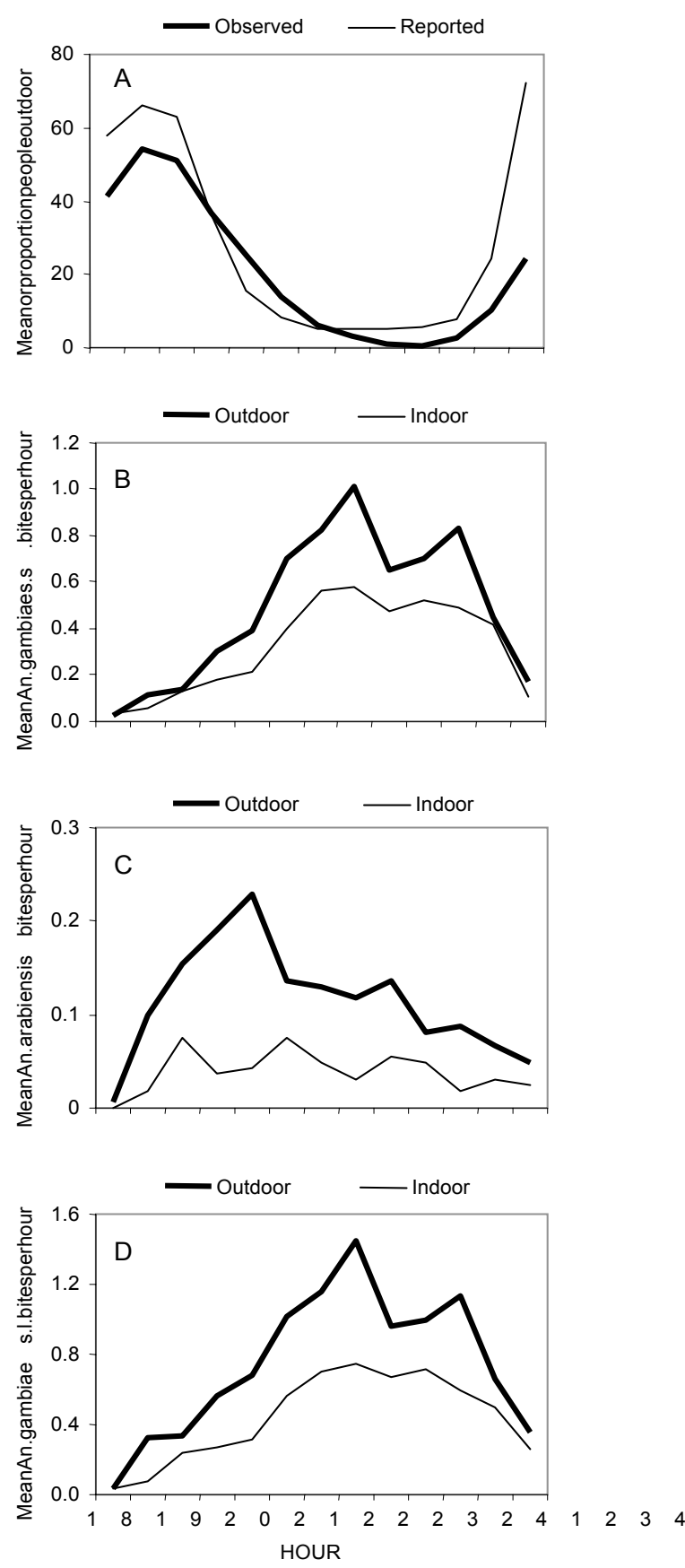

\section{Figure 3}

Human and mosquito behavioural patterns in Dar es Salaam, Tanzania. A. Number or proportion of time residents spend outdoors, comparing what they reported themselves with direct observations in the field. B. Mean numbers of An. gambiae s.s caught indoors and outdoors. C. Mean number of $A n$. arabiensis caught indoors and outdoors. D. Mean number of An. gambiae s.l. caught indoors and outdoors.

\section{Detailed focal surveys of household and personal protection}

A total of 2,153 people were living in these 216 houses at the time of survey, of whom approximately half were under the age of 22 (Table 3). All the TCU were either near a swamp or close to a depression with poorly functioning drains and most of these areas were partially flooded during the rains. Although these were mostly poorer, unplanned areas, half of the houses had intact screening or screening with small holes. Almost three quarters of these houses did not have a ceiling board and it was typically observed that the eaves of most houses in Dar es Salaam were accessible to mosquitoes. Although more than three quarters of residents slept under a net, only a third of these nets had ever been treated with insecticide. Very few residents reported using alternative protective measures such as repellents, mosquito coils or insecticidal sprays (Table 3 ).

\section{Human-mosquito behavioural interactions}

The reported and observed behaviours of humans were largely consistent (Figure 3A). The minor discrepancies can be explained as follows. Less people were observed than reported outdoors in the evenings and mornings, because it was not possible for us to enter all courtyards and some individuals may be elsewhere during these hours. More people were observed than reported to be outdoors towards midnight but, based on direct experience, this was attributed to the transition of people through the TCU who do not live there. The residents reported that shortly after $10 \mathrm{pm}, 50 \%$ of the people had gone to bed and at around 6 am $50 \%$ of the people were still asleep. A small, but noteworthy, proportion of residents slept outdoors all night (Table 3), often citing heat and poor ventilation inside the house as their primary motivation.

During the intensive entomological study in the selected sites with high An. gambiae densities, 432 catcher-nights yielded 2,484 An. gambiae s.l., 63 An. funestus, 370 An. coustani, 41,290 Culex, 70 Aedes and 97 Mansonia. Of the 2,027 An. gambiae s.l. which were successfully amplified, 83. $3 \%, 15.9 \%$ and $0.2 \%$ were identified as An. gambiae s.s., An. arabiensis and An. merus, respectively. Only $0.41 \%$ (7/1700) of An. gambiae s.s. and $0.31 \%(1 / 322)$ and $A n$. arabiensis were found to be infected with sporozoites. $A n$. gambiae s.s., An arabiensis, An. funestus, An. coustani and Mansonia were all exophagic, meaning that they mainly bite outdoors [100] as evidenced by the proportion of mosquitoes caught outside being significantly greater than half (Figures 3 and 4). Anopheles gambiae s.l. is generally endophagic in rural Tanzania $[36,87,101]$ and the proportion of An. gambiae s.l. caught outdoors was higher in Dar es Salaam than in Kilombero valley (Figure 4; 63 versus $34 \%$, respectively; $\mathrm{X}^{2}=597.1, \mathrm{P}<0.001$ ), considering only catches up to 6 am because the studies in Kilombero valley stopped at this time. In Dar es Salaam, the 


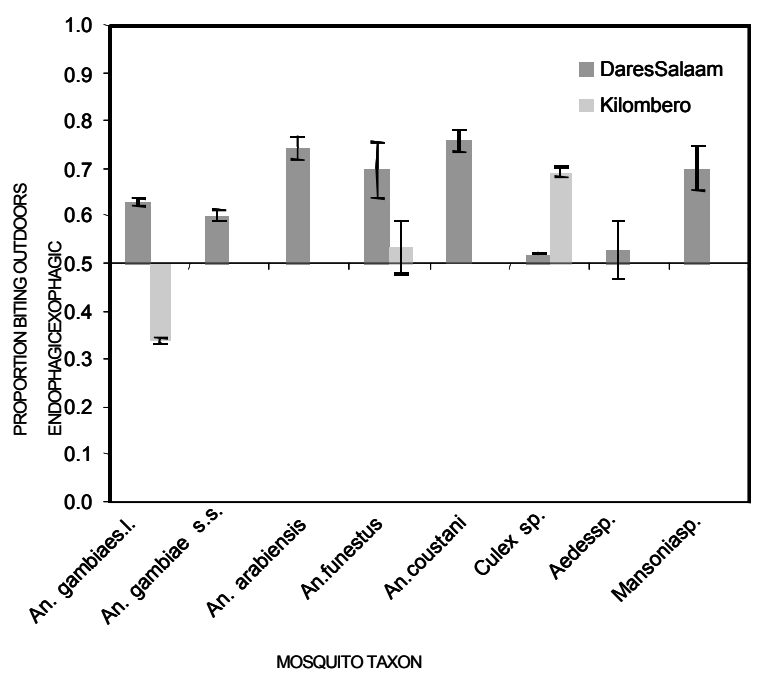

Figure 4

Comparison of exophagic and endophagic behaviour of different mosquito species in urban and rural Tanzania. Degree of exophagy or endophagy is presented as the proportion of mosquitoes caught outdoors so that all mosquitoes with a proportion of outdoor biting significantly greater than 0.5 are considered to be exophagic and all below 0.5 are considered endophagic.

proportion of An. arabiensis caught outdoors was significantly higher than the proportion of An. gambiae s.s. caught outdoors $\left(\mathrm{X}^{2}=23.4\right.$, P-value $\left.<0.001\right)$. Culex sp. and Aedes sp. exhibited neither exo- nor endophagic tendencies in Dar es Salaam.

Hourly biting pattern almost exactly followed classically reported patterns of An. gambiae s.l. [87] with an increase of Anopheles gambiae s.s. densities towards midnight, and a second peak around $4-5 \mathrm{am}$, followed by a decline towards dawn (Figure 3B). In fact, the proportions of $A n$. gambiae s.s mosquitoes caught during peak sleeping hours was greater in the city than in the rural area $\left(\mathrm{X}^{2}=112.9, \mathrm{P}\right.$ $<0.001$ ) with peak sleeping hours in Kilombero valley from $9 \mathrm{pm}$ to $5 \mathrm{am}$ and in Dar es Salaam from $10 \mathrm{pm}$ to 6 $\mathrm{am}$. As summarized in Figure 4, biting activity was more intense outdoors than indoors throughout the night and was highest during sleeping hours (Figure 3B). An. gambiae s.s. constituted $84 \%$ of An. gambiae s.l. and therefore dominates the shape of the curve for the pooled sibling species (Figure 3D). Nevertheless, it is noteworthy that An. arabiensis had its peak biting time at $10 \mathrm{pm}$, when more than three quarters of the residents were still awake, and then slowly declined towards the morning (Figure 3C).
Combining the human and mosquito behavioural surveys, and using the model described in the methods section, allowed estimation of the biting rates experienced by residents at each hour of the night (Figure 5). This approach also allowed dissection of these mosquitohuman interactions into distinct domestic compartments (Figure 6) where specific interventions may or may not reduce exposure. For example, ITNs are expected only to provide personal protection while sleeping so their protective efficacy is limited to those times of the night when users sleep and cannot exceed the proportion of exposure which would otherwise occur while asleep $\left(\pi_{\mathrm{s}}\right.$; equation 6). In contrast, interventions which prevent house entry, such as mosquito proofing $[60,61]$ or spatial repellents such as DDT [100], could prevent any indoor exposure regardless of whether occupants are awake or in bed $\left(\pi_{\mathrm{i}}\right.$; equation 8). It should be noted that the simpler form of this approach applied previously [85] did not allow estimation of exposure indoors while awake so it is not possible to compare Dar es Salaam with this rural precedent in terms of the relative contributions of exposure indoors and outdoors while awake. Nevertheless, it is possible to
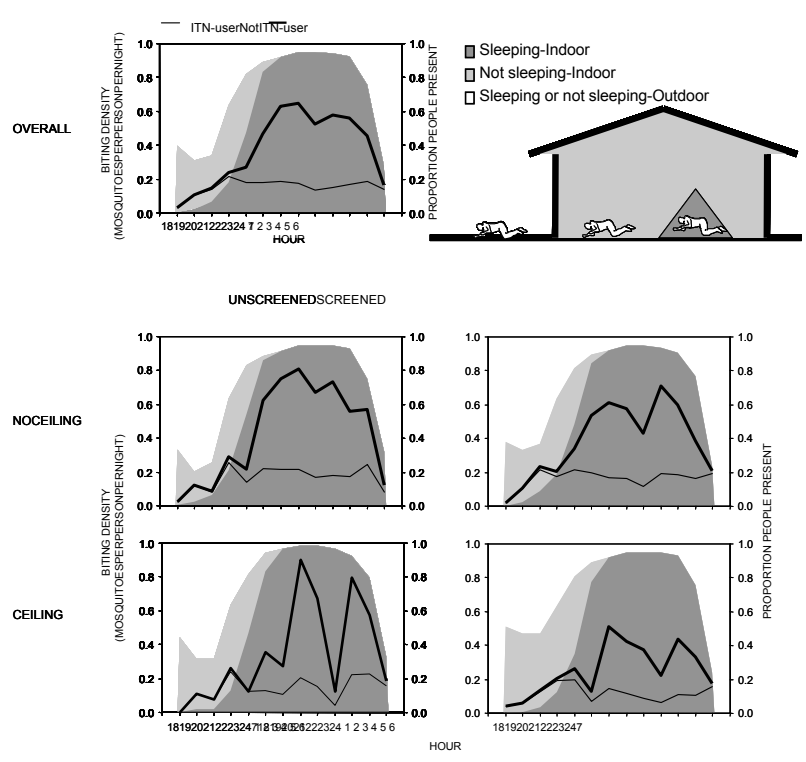

\section{Figure 5}

Exposure to biting of An. gambiae s.s. for ITN users and nonusers. The shadings represent the proportion of time spend in each compartment (outdoor; $\mathrm{I}-\pi_{i}$; equation 8 , indoor awake; $\pi_{\mathrm{a}}$; equation 7 , indoor asleep; $\pi_{\mathrm{s}}$; equation 6). Exposure to biting is shown overall as well as for different house qualities: Screened (Glass windows, screening with no or small holes), unscreened (no screening or badly torn/incomplete screens), ceiling (complete ceiling or partly ceiling), no ceiling (no ceiling board). 
Table 2: Protection measures against mosquitoes in urban Dar es Salaam in the past and present, in rural Tanzania and in two Kenyan cities

\begin{tabular}{|c|c|c|c|c|c|c|c|c|c|c|c|c|c|c|}
\hline \multirow[t]{2}{*}{ Location } & \multicolumn{2}{|c|}{ Net usage } & \multicolumn{3}{|c|}{ Net treatment status } & \multicolumn{5}{|c|}{ Window screening } & \multicolumn{4}{|c|}{ Other protection measures } \\
\hline & $\%$ & $\mathrm{~N}$ & $\begin{array}{c}\text { In the last } 6 \\
\text { months }\end{array}$ & $\begin{array}{c}\text { More } \\
\text { than } 6 \\
\text { months }\end{array}$ & never & intact & $\begin{array}{l}\text { Small } \\
\text { holes }\end{array}$ & $\begin{array}{l}\text { Big } \\
\text { holes }\end{array}$ & $\begin{array}{c}\text { Glass } \\
\text { windows }\end{array}$ & none & Coil & repellent & spray & none \\
\hline \multicolumn{15}{|c|}{ Urban Kenya and Tanzania } \\
\hline $\begin{array}{l}\text { Dar es } \\
\text { Salaam; } \\
\text { 2006a }\end{array}$ & 78.8 & 1696 & 35.9 & 0.6 & 63.5 & 17.3 & 39.6 & 14.7 & 0.4 & 28 & 9.2 & 7.3 & 15.9 & 67.6 \\
\hline $\begin{array}{l}\text { Dar es } \\
\text { Salaam; } \\
\text { I994 [34] }\end{array}$ & 62 & & & & & & & & & & 52 & - & 30 & 18 \\
\hline $\begin{array}{l}\text { Kisumu, } \\
\text { Kenya; 200I } \\
\text { [99] }\end{array}$ & 56 & 287 & & & & & 5 & & & 95 & 40 & 0.008 & 13 & 47 \\
\hline $\begin{array}{l}\text { Malindi, } \\
\text { Kenya; 200I } \\
\text { [99] }\end{array}$ & 69 & 332 & & & & & 32 & & & 68 & 54 & 27 & 5 & 14 \\
\hline \multicolumn{15}{|c|}{ Rural Reference Site } \\
\hline $\begin{array}{l}\text { Kilombero, } \\
\text { Valley } \\
\text { Tanzania;20 } \\
03 \text { (Killeen } \\
\text { et al. } \\
\text { unpublished } \\
\text { ) }\end{array}$ & 74.5 & 650 & 4.7 & 6.6 & 88.7 & & & & & & & & $1.4^{b}$ & 98.6 \\
\hline
\end{tabular}

a Data derived from the study presented here.

b Any type of protection measures (spray, coil, herbal, physical)

compare the proportion of exposure which an ITN might be expected to prevent ( $\pi_{\mathrm{s}}$; equation $\left.\mathbf{6}\right)$.

Even though An. gambiae s.s. were exophagic in urban Dar es Salaam, a high quality ITN was expected to confer $59 \%$ protection against exposure to this mosquito for a typical resident in a typical house. Although such protection against exposure is clearly incomplete, it is almost as high as the $70 \%$ protection afforded against highly endophagic An. gambiae in rural Kilombero [85] which is known to provide effective protection against clinical disease even in this highly endemic rural setting $[102,103]$. This slightly lower level of protection against exposure is because the number of bites which normally occur indoors and during sleeping hours were lower in the city (79\% and $74 \%$, respectively) than in the rural area $(90 \%$ and $80 \%$, respectively). The less abundant An. arabiensis was not only exophagic in Dar es Salaam but also most active just before $10 \mathrm{pm}$ (Figure 3C) so the personal protection by an ITN against exposure to this species is estimated to be only $38 \%$.

\section{Interdependence of protection measures and mosquito densities}

Members of the An. gambiae s.l. complex dominated malaria transmission in Dar es Salaam and, of these, only An. gambiae s.s. was present in sufficient numbers to undertake the following analysis in a meaningful way. The following results only describe those for An. gambiae s.s., as confirmed by PCR, and assume it is responsible for essentially all transmission in the study area. In wellscreened (glass windows, screening with no or small holes) and houses with complete ceiling boards (complete and partly ceiling board) ITNs conferred slightly less protection against An. gambiae s.s. because the proportion (Figures 5 and 6) and total (Figure 7) levels of exposure in such houses that occurred indoors were lower. It should be noted that much of the reduction of proportional and total exposure achieved with screening and ceilings resulted from adaptive changes in human behaviour with occupants spending more of their waking hours in the safer confines of the house (Figures 6 and 7).

Exploratory pair-wise correlation analysis showed that complete ceilings were associated with use of other protection methods $\left(\mathrm{r}^{2}=0.323, \mathrm{P}<0.01\right)$ and good house screening $\left(\mathrm{r}^{2}=0.267, \mathrm{P}<0.01\right)$, which was in turn associ- 


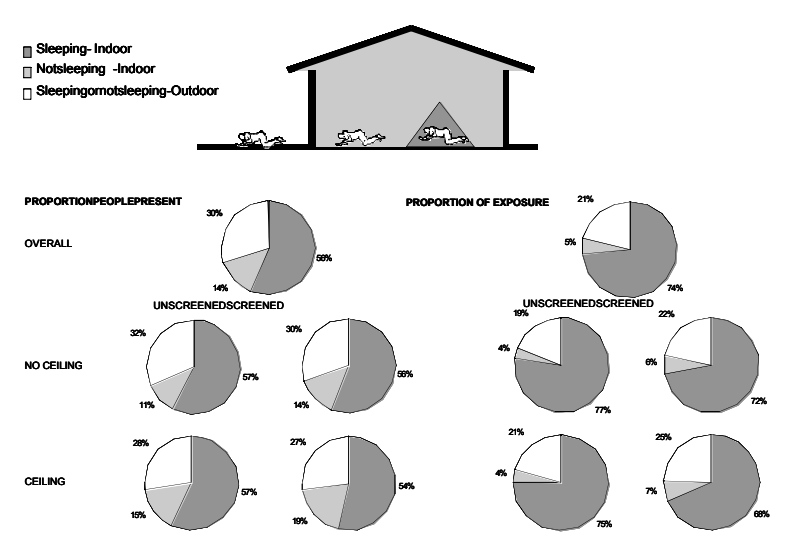

\section{Figure 6}

Proportion of people present in each compartment and their estimated exposure if not using a bednet (outdoor; $\mathrm{I}-\pi_{\mathrm{i}}$; equation $\mathbf{8}$, indoor awake; $\pi_{\mathrm{a}}$; equation $\mathbf{7}$, indoor asleep; $\pi_{\mathrm{s}}$; equation 6), presented as an overall mean and for categories of different house qualities: Screened (Glass windows, screening with no or small holes), unscreened (no screening or badly torn), ceiling (complete ceiling or partly ceiling), no ceiling (no ceiling board).

ated with high outdoor densities of Culex sp $\left(\mathrm{r}^{2}=0.136, \mathrm{P}\right.$ $<0.05)$. Interestingly, use of ITNs was associated with high indoor densities of Culex sp $\left(\mathrm{r}^{2}=0.137, \mathrm{P}<0.05\right)$ and use of any bednet was negatively correlated with complete ceilings $\left(\mathrm{r}^{2}=-0.194, \mathrm{P}<0.01\right)$ and other protection methods $\left(\mathrm{r}^{2}=-0.209, \mathrm{P}<0.01\right)$. This suggests that installation and maintenance of ceilings and screening, is motivated by local densities of nuisance mosquitoes whereas use of bednets may be a response to the failure or inability to apply these for socioeconomic reasons. The overall biting densities of An. gambiae showed only a negative association with complete ceilings $\left(\mathrm{r}^{2}=-0.160, \mathrm{P}<0.05\right)$ and good screening $\left(\mathrm{r}^{2}=-0.136, \mathrm{P}<0.05\right)$, suggesting that this vector species contributes little to motivating their utilization. Also, consistent with their known preference for eave entry and the results presented in figures 6 and 7, ceilings do confer protection against exposure to malaria transmission as does, to a lesser extent, good screening.

Principal component analysis of the relationship between vector densities and the various protection measures surveyed revealed three important factors (Table 4), suggesting that the uptake and use of these interventions is driven by a number of motivations and constraints in a complex manner (Figure 8). Interestingly, Factor 2 shows clear increase in use of all protective measures associated with increased density of Culex sp. but not An. gambiae s.l., probably reflecting the motivation for uptake of all interventions at high densities of nuisance biting. Factors 1 and

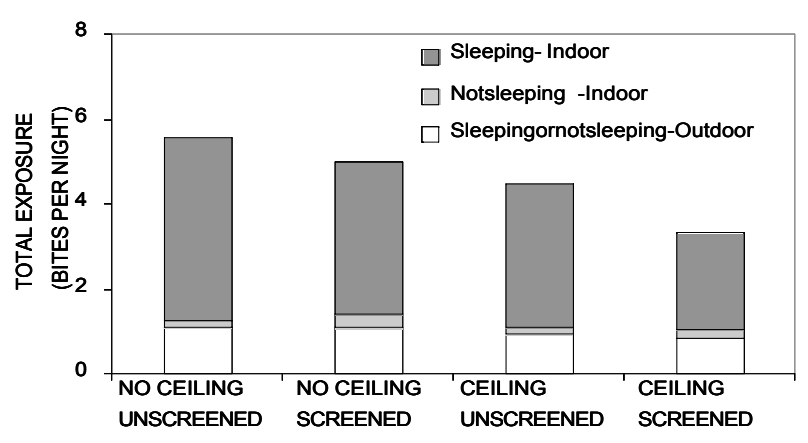

Figure 7

Mean number of bites received by a person in each of the three domestic and peri-domestic compartments (outdoor; $\mathrm{I}-\pi_{\mathrm{i}}$; equation $\mathbf{8}$, indoor awake; $\pi_{\mathrm{a}}$; equation $\mathbf{7}$, indoor asleep; $\pi_{s}$; equation 6 ).

3 seem to reflect quite different underlying motivations or limitations that determine intervention utilization at household level and interact to a greater or lesser extent with mosquito density. Factor 1 shows a clear association of mosquito proofed houses with low usage rates of treated or untreated bednets and with high usage rates of other protective measures. This maybe reflects the influence of socioeconomic status on the choices of interventions used by households with mosquito-proofing and other measures probably being associated with better households while bednets may be utilized to a greater extent in houses which cannot afford these. Factor 3 appears to be almost completely independent of bednet use, but exhibits a clear association of the use of other interventions with high densities of An. gambiae s.l. and poor or absent window screening. It is suggested that factor three reflects the response of residents to indoor exposure to An. gambiae, perhaps as a proxy for malaria transmission, when window screening is not present. However these suggestions have to be looked at with caution as they remain speculative until such surveys of practice are conducted on larger population scales and complemented with direct evaluations of socioeconomic and educational status, as well as associated knowledge and attitudes.

\section{Conclusion}

Although the hourly biting pattern of An. gambiae s.s. remains essentially consistent with classical reports, An. arabiensis appears to have a much earlier peak biting time at $10 \mathrm{pm}$ when a large proportion of people are still outdoors. ITNs confer little protection against exposure to this species, which is fortunately relatively rare in urban Dar es Salaam. Anopheles arabiensis only account for $16 \%$ of the An. gambiae complex in Dar es Salaam, so ITNs still provide useful individual protection. However, the obser- 
Table 3: House characteristics and human behaviour traits (time period from February to June 2006) of the areas in Dar es Salaam where mosquitoes were sampled indoors and outdoors

\begin{tabular}{|c|c|c|}
\hline \multirow[t]{2}{*}{ Characteristic } & \multicolumn{2}{|c|}{ Frequency } \\
\hline & $\mathrm{N}$ & $\%$ \\
\hline \multicolumn{3}{|l|}{ Age } \\
\hline$<1$ year & 62 & 2.9 \\
\hline $1-5$ years & 231 & 10.7 \\
\hline $6-14$ years & 403 & 18.7 \\
\hline$>14$ years & 1457 & 67.7 \\
\hline \multicolumn{3}{|l|}{ Ceiling board } \\
\hline Whole house & 37 & 16.6 \\
\hline Partly & 27 & 12.1 \\
\hline None & 159 & 71.3 \\
\hline \multicolumn{3}{|l|}{ Screening } \\
\hline Intact & 44 & 19.7 \\
\hline With holes & 90 & 40.4 \\
\hline Incomplete & 31 & 13.9 \\
\hline Glass windows & 2 & 0.9 \\
\hline None & 56 & 25.1 \\
\hline \multicolumn{3}{|l|}{ Bednet usage } \\
\hline Overall & 1695 & 78.8 \\
\hline$<1$ year & 53 & 96.4 \\
\hline $1-5$ years & 213 & 92.6 \\
\hline $6-14$ years & 322 & 79.9 \\
\hline$>14$ years & 1107 & 76 \\
\hline \multicolumn{3}{|l|}{ Treatment status of net } \\
\hline Treated in last 6 months & 774 & 35.9 \\
\hline Treated more than 6 months ago & 11 & 0.6 \\
\hline Never treated & 1368 & 63.5 \\
\hline \multicolumn{3}{|l|}{ Other protection against mosquitoes } \\
\hline Coil & 198 & 9.2 \\
\hline Spray & 343 & 15.9 \\
\hline Repellent & 158 & 7.3 \\
\hline None & 1454 & 67.6 \\
\hline \multicolumn{3}{|l|}{ Eating location } \\
\hline Indoor & 783 & 74.1 \\
\hline Outdoor & 270 & 25.6 \\
\hline Other & 3 & 0.3 \\
\hline \multicolumn{3}{|l|}{ Dinner time } \\
\hline Before 7 pm & 59 & 5.6 \\
\hline Between 7 and $8.30 \mathrm{pm}$ & 492 & 46.6 \\
\hline After $8.30 \mathrm{pm}$ & 505 & 47.8 \\
\hline \multicolumn{3}{|l|}{ Resting location after dinner } \\
\hline Indoor & 505 & 47.8 \\
\hline Outdoor & 540 & 51.1 \\
\hline Other or don't know & 11 & 1.1 \\
\hline \multicolumn{3}{|l|}{ Bedtime } \\
\hline Before 6 pm & 3 & 0.3 \\
\hline Between 6 and 7 pm & 18 & 1.7 \\
\hline Between 7 and 8 pm & 48 & 4.5 \\
\hline Between 8 and 9 pm & 117 & 11.1 \\
\hline Between 9 and 10 pm & 312 & 29.5 \\
\hline Between 10 and 11 pm & 379 & 35.9 \\
\hline Between 11 and $12 \mathrm{pm}$ & 125 & 11.8 \\
\hline After $12 \mathrm{pm}$ & 53 & 5 \\
\hline Don't know & 1 & 0.1 \\
\hline \multicolumn{3}{|l|}{ Waking time } \\
\hline Before 4 am & 4 & 0.4 \\
\hline Between 4 and 5 am & 23 & 2.2 \\
\hline Between 5 and 6 am & 173 & 16.4 \\
\hline Between 6 and 7 am & 509 & 48.2 \\
\hline After $7 \mathrm{am}$ & 346 & 32.8 \\
\hline Don't know/didn't respond & 1 & 0.1 \\
\hline \multicolumn{3}{|l|}{ Sleeping location } \\
\hline Outdoor sleeping & 56 & 5.3 \\
\hline Indoor sleeping & 1000 & 94.7 \\
\hline
\end{tabular}




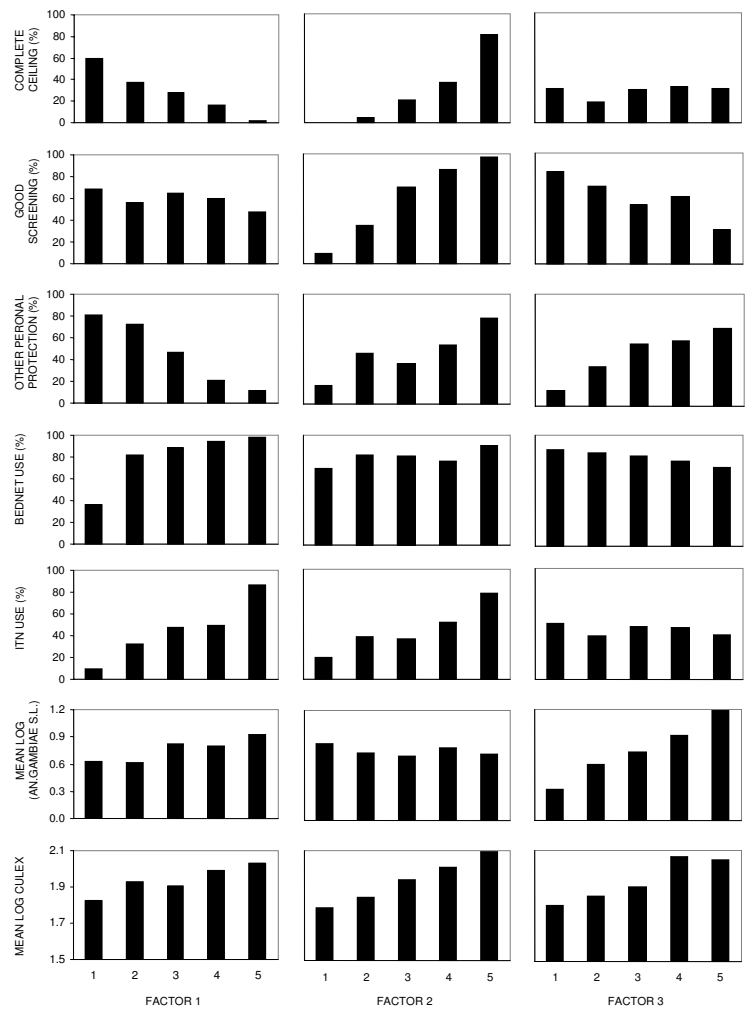

Figure 8

Three factors derived through principal component analysis and their association with different protective measures as well as mosquito densities.

vations from Dar es Salaam can have greater implications for malaria control in Africa where An. arabiensis is a very common and an important vector $[5,88,104]$. It cannot be determined whether the early biting of An. arabiensis in Dar es Salaam was induced by ITN use and/or improved housing quality. In this context, it seems relevant to note that this An. arabiensis is more tolerant to desiccation than An. gambiae $[88,105,106]$ and may, therefore, be able to adapt more readily to earlier feeding despite the relatively low humidity that occurs in the early evening. The surprisingly exophagic behavior of An. gambiae in Dar es Salaam may also arise from increased bednet coverage as well as housing quality. This is consistent with another recently reported urban context [80] and an increasing number of sites in rural Africa [107-111].

Despite the clear exophagy of malaria vectors in Dar es Salaam, like elsewhere in Africa, ITNs confer useful but incomplete personal protection [59,112]. Much bigger reductions of transmission can be attained at community
Table 4: Protective measures, malaria and nuisance mosquito densities and their scores in three different factors and the percent of the variance these factors account for derived through principal component analysis.

\begin{tabular}{|c|c|c|c|c|}
\hline & & Factor I & Factor 2 & Factor 3 \\
\hline & $\begin{array}{l}\% \text { of } \\
\text { Variance }\end{array}$ & 24.55 & 21.41 & 15.67 \\
\hline \multirow[t]{7}{*}{ Scores } & $\begin{array}{l}\text { Complete } \\
\text { ceilinga }\end{array}$ & -0.477 & 0.646 & 0.039 \\
\hline & $\begin{array}{l}\text { Good } \\
\text { screeningb }\end{array}$ & -0.155 & 0.629 & -0.362 \\
\hline & $\begin{array}{l}\text { Other } \\
\text { personal } \\
\text { protectionc }\end{array}$ & -0.528 & 0.392 & 0.374 \\
\hline & Bednet use & 0.773 & 0.236 & -0.223 \\
\hline & ITN use & 0.628 & 0.508 & -0.076 \\
\hline & $\begin{array}{l}\text { Mean log } \\
\text { (An. } \\
\text { gambiae s.l.) }\end{array}$ & 0.334 & -0.068 & 0.764 \\
\hline & $\begin{array}{l}\text { Mean log } \\
\text { Culex }\end{array}$ & 0.289 & 0.463 & 0.430 \\
\hline
\end{tabular}

a Complete and partly complete ceiling board

bScreening without holes, with small holes or glass windows

c Coils, spray and/or repellent

level where high population coverage is achieved $[44,95,113,114]$. Although additional vector control measures are desirable to cope with the remaining quarter of human exposure which occurs outdoors, ITNs should remain a high priority in urban settings. ITNs appear to be a second preference intervention in Dar es Salaam, with mosquito-proofing of houses being the most commonly implemented measure and probably the first choice of residents. It may, therefore, be feasible to develop programmes which promote and subsidize such efforts by vulnerable households to tackle their local malaria problems. Additional important options to prevent outdoor transmission include larviciding $[115,116]$ and environmental management [117-119], all of which merit further development as components of integrated programmes [1] in the tropical belt of Africa, where malaria transmission is at its most intense [5].

\section{Competing interests}

Part of the Urban Malaria Control Programme is financed by Valent Biosciences Corporation, a manufacturer of microbial larvicides. A substantial portion of the current salary and research support for the investigators depends on the achievement of documented suppression of malaria transmission and infection risk by this programme through systematic larviciding.

\section{Authors' contributions}

YG designed and implemented the study, analysed the data and drafted the manuscript. PC, BE, NJG, RS, VM, $\mathrm{DM}, \mathrm{HM}, \mathrm{UF}$, SWL and KK were involved in designing and implementation the study. MCdC, MT and GFK partici- 
pated in the study design, data analysis and drafting of the manuscript. All authors read and approved the final manuscript.

\section{Acknowledgements}

We thank the entire team who participated in these surveys but especially those who conducted human landing catch studies for their perseverance and commitment to this challenging undertaking. Furthermore we would like to thank the residents of Dar es Salaam for their cooperation and facilitation during our regular visits. We thank A. Mtandanguo, A. Mariwa, A. Hemedi and J.E. Msami in helping with the mosquito identification. We would also like to thank D.R. Nyika and C.B. Buberwa for drafting the map of the study area. This paper is published with kind permission of Dr. Andrew Kitua, Director of the National Institute for Medical Research, United Republic of Tanzania.

Research and ethical clearance were obtained from the Medical Research Coordination Committee of the National Institute for Medical Research through the Tanzanian commission for Science \& Technology. This study was supported financially by the Swiss Tropical Institute, the Bill and Melinda Gates Foundation, Valent Biosciences and USAID through its Environmental Health Programme, the Tanzanian Mission at Dar es Salaam and the Presidents Malaria Initiative. GFK is supported by the Wellcome Trust through Research Career Development Fellowship number 076806.

\section{References}

I. WHO: Global Strategic Framework for Integrated Vector Management. Geneva, World Health Organization; 2004:I5.

2. Snow RW, Guerra CA, Noor AM, Myint HY, Hay SI: The global distribution of clinical episodes of Plasmodium falciparum malaria. Nature 2005, 434(7030):2I4-217.

3. Hay SI, Guerra CA, Tatem TA, Noor AM, Snow RW: The global distribution and population at risk of malaria: past, present and future. Lancet Infectious Dis 2004, 4:327-336.

4. RollBackMalariaPartnership : World Malaria Report. Geneva , World Health Organization; 2005.

5. Kiszewski A, Mellinger A, Spielman A, Malaney P, Sachs SE, Sachs J: A global index representing the stability of malaria transmission. Am J Trop Med Hyg 2004, 70(5):486-498.

6. Robert V, Maclntyre K, Keating J, Trape JF, Duchemin JB, Warren M, Beier JC: Malaria transmission in urban sub-Saharan Africa. Am J Trop Med Hyg 2003, 68(2):169-176.

7. Keiser J, Utzinger J, Castro MC, Smith TA, Tanner M, Singer BH: Urbanization in sub-Saharan Africa and implication for malaria control. Am J Trop Med Hyg 2004, 7 I (2 Suppl): I I8-I 27.

8. Donnelly MJ, McCall PJ, Lengeler C, Bates I, D'Alessandro U, Barnish G, Konradsen F, Klinkenberg E, Townson H, Trape JF, Hastings IM, Mutero C: Malaria and urbanization in sub-Saharan Africa. Malar J 2005, 4(I): 12 .

9. Wang SJ, Lengeler C, Smith TA, Vounatsou P, Cisse G, Diallo DA, Akogbeto M, Mtasiwa D, Teklehaimanot A, Tanner M: Rapid urban malaria appraisal (RUMA) in sub-Saharan Africa. Malar J 2005, 4:40.

10. Hay SI, Guerra CA, Tatem AJ, Atkinson PM, Snow RW: Urbanization, malaria transmission and disease burden in Africa. Nat Rev Microbiol 2005, 3:8I-90.

II. Lines J, Harpham T, Leake C, Schofield C: Trends, priorities and policy directions in the control of vector-borne diseases in urban environments. Health Policy and Plan 1994, 9(2): I I3-129.

12. UN: World urbanization prospects: the 2003 revision. Data, tables and highlights (online). 2004 [http://www.un.org/esa/pop ulation/publications/wup2003/2003WUPHighlights.pdf].

13. Smith T, Maire N, Dietz K, Killeen GF, Vounatsou P, Molineaux L, Tanner M: Relationship between the entomologic inoculation rate and the force of infection for Plasmodium falciparum malaria. Am J Trop Med Hyg 2006, 75(2 Suppl): I I-18.

14. Ross A, Maire N, Molineaux L, Smith T: An epidemiologic model of severe morbidity and mortality caused by Plasmodium falciparum. Am J Trop Med Hyg 2006, 75(2 Suppl):63-73.
15. Ross A, Killeen G, Smith T: Relationships between host infectivity to mosquitoes and asexual parasite density in Plasmodium falciparum. Am J Trop Med Hyg 2006, 75(2 Suppl):32-37.

16. Trape JF, Pison G, Spiegel A, Enel C, Rogier C: Combating malaria in Africa. Trends Parasitol 2002, I 8(5):224-230.

17. Trape JF, Zoulani A: Malaria and urbanization in Central Africa: the example of Brazzaville. Part III: Relationship between urbanization and the intensity of malaria transmission. Trans $R$ Soc Trop Med Hyg 1987, 8 I (Supplement 2): 19-25.

18. Trape JF, Zoulani A: Malaria and urbanization in Central Africa: the example of Brazzaville. Part II: Results of entomological surveys and epidemiological analysis. Trans $R$ Soc Trop Med Hyg 1987, 8 I (Supplement 2): I0- I8.

19. Trape JF, Lefebvre-Zante E, Legros F, G. N, Bouganali H, Druilhe P, Salem G: Vector density gradients and the epidemiology of urban malaria in Dakar, Senegal. Am J Trop Med Hyg 1992, 47(2): $181-189$.

20. Eisele TP, Keating J, Swalm C, Mbogo CM, Githeko AK, Regens JL, Githure Jl, Andrews L, Beier JC: Linking field-based ecological data with remotely sensed data using a geographic information system in two malaria endemic urban areas of Kenya. Malar J 2003, 2(1):44.

21. Castro MC, Yamagata Y, Mtasiwa D, Tanner M, Utzinger J, Keiser J, Singer BH: Integrated urban malaria control: a case study in Dar es Salaam, Tanzania. Am J Trop Med Hyg 2004, 7 I(2 Suppl): I03-I I7.

22. Thompson R, Begtrup K, Cuamba N, Dgedge M, Mendis C, GamageMendis A, Enosse SM, Barreto J, Sinden RE, Hogh B: The Matola malaria project: A temporal and spatial study of malaria transmission and disease in a suburban area of Maputo, Mozambique. Am J Trop Med Hyg 1997, 57(5):550-559.

23. Staedke SG, Nottingham EW, Cox J, Kamya MR, Rosenthal PJ, Dorsey G: Short report: proximity to mosquito breeding sites as a risk factor for clinical malaria episodes in an urban cohort of Ugandan children. Am J Trop Med Hyg 2003, 69(3):244-246.

24. Trape JF: Malaria and urbanization in Central Africa: the example of Brazzaville. Part IV: Parasitological and serological surveys in urban and surrounding areas. Trans $R$ Soc Trop Med Hyg 1987, 8 I (supplement 2):26-33.

25. Minakawa N, Seda P, Yan G: Influence of host and larval habitat distribution on the abundance of African malaria vectors in Western Kenya. Am J Trop Med Hyg 2002, 67(I):32-38.

26. Service MW: Mosquito (Diptera: Culicidae) dispersal--the long and short of it. J Med Entomol 1997, 34(6):579-588.

27. Killeen GF, Knols BG, Gu W: Taking malaria transmission out of the bottle: implications of mosquito dispersal for vector-control interventions. Lancet Infect Dis 2003, 3(5):297-303.

28. Le Menach A, McKenzie FE, Flahault A, Smith DL: The unexpected importance of mosquito oviposition behaviour for malaria: non-productive larval habitats can be sources for malaria transmission. Malar J 2005, 4(I):23.

29. Smith DL, Dushoff J, McKenzie FE: The risk of a mosquito-borne infection in a heterogeneous environment. PLOS Biol 2004, 2(II):e368.

30. Stephens C, Masamu ET, Kiama MG, Keto AJ, Kinenekejo M, Ichimori $\mathrm{K}$, Lines J: Knowledge of mosquitos in relation to public and domestic control activities in the cities of Dar es Salaam and Tanga. Bull World Health Organ 1995, 73(I):97-104.

3I. Curtis C, Maxwell C, Lemnge M, Kilama WL, Steketee RW, Hawley WA, Bergevin Y, Campbell CC, Sachs J, Teklehaimanot A, Ochola S, Guyatt H, Snow RW: Scaling-up coverage with insecticidetreated nets against malaria in Africa: who should pay? Lancet Infect Dis 2003, 3(5):304-307.

32. Lines J, Lengeler $C$, Cham K, de Savigny D, Chimumbwa J, Langi $P$, Carroll D, Mills A, Hanson K, Webster J, Lynch M, Addington W, Hill J, Rowland M, Worrall E, MacDonald M, Kilian A: Scaling-up and sustaining insecticide-treated net coverage. Lancet Infect Dis 2003, 3(8):465-6; discussion 467-8

33. Wang SJ, Lengeler C, Mtasiwa D, Mshana T, Manane L, Maro G, Tanner M: Rapid urban malaria appraisal (RUMA) II: Epidemiology of urban malaria in Dar es Salaam (Tanzania). Malar J 2006, 5(I):29.

34. Evans PJ: Community knowledge, attitudes and practicesurban mosquitoes and sustainable mosquito control. In Faculty of Social Studies University of Exeter; 1994:308. 
35. Wang S), Lengeler C, Smith TA, Vounatsou P, Akogbeto M, Tanner M: Rapid Urban Malaria Appraisal (RUMA) IV: epidemiology of urban malaria in Cotonou (Benin). Malar J 2006, 5:45.

36. Pates $\mathrm{H}$, Curtis $\mathrm{C}$ : Mosquito behavior and vector control. Annu Rev Entomol 2005, 50:53-70.

37. Carnevale P, Robert V, Boudin C, Halna JM, Pazart L, Gazin P, Richard A, Mouchet J: La lutte contre le plaudisme par des moustiquaires impregnees de pyrethroides au Burkina Faso. Bull Soc Pathol Exot Filiales I 988, 8 I(5):832-846.

38. Curtis CF, Maxwell CA, Finch RJ, Njunwa KJ: A comparison of use of a pyrethroid either for house spraying or for bednet treatment against malaria vectors. Trop Med Int Health 1998, 3(8):619-63|.

39. Karch S, Garin B, Asidi N, Manzambi Z, Salaun J], Mouchet J: [Mosquito nets impregnated against malaria in Zaire]. Ann Soc Belg Med Trop 1993, 73(I):37-53.

40. Jaenson TG, Gomes MJ, Barreto dos Santos RC, Petrarca V, Fortini D, Evora J, Crato J: Control of endophagic Anopheles mosquitoes and human malaria in Guinea Bissau, West Africa by permethrin-treated bed nets. Trans $R$ Soc Trop Med Hyg 1994, 88(6):620-624.

41. Knols BGJ, Takken W: The widescale use of impregnated bednets for malaria control in Africa: impact on mosquitoes. Proc Exp Appl Entomol 1998, 8:15-20.

42. Magesa SM, Wilkes TJ, Mnzava AEP, Njunwa KJ, Myamba J, Kivuyo MDP, Hill N, Lines JD, Curtis CF: Trial of pyrethroid impregnated bednets in an area of Tanzania holoendemic for malaria. Part 2 Effects on the malaria vector population. Acta Trop 199I, 49:97-I08.

43. Maxwell CA, Chambo W, Mwaimu M, Magogo F, Carneiro IA, Curtis CF: Variation of malaria transmission and morbidity with altitude in Tanzania and with introduction of alphacypermethrin treated nets. Malar J 2003, 2(I):28.

44. Maxwell CA, Msuya E, Sudi M, Njunwa KJ, Carneiro IA, Curtis CF: Effect of community-wide use of insecticide-treated nets for 3-4 years on malarial morbidity in Tanzania. Trop Med Int Health 2002, 7( I 2): 1003-1008.

45. Maxwell CA, Myamba J, Njunwa KJ, Greenwood BM, Curtis CF: Comparison of bednets impregnated with different pyrethroids for their impact on mosquitoes and on re-infection with malaria after clearance of pre-existing infections with chlorproguanil-dapsone. Trans R Soc Trop Med Hyg 1999, 93(I):4-II.

46. Mbogo CNM, Baya NM, Ofulla AVO, Githure JI, Snow RW: The impact of permethrin-impregnated bednets on malaria vectors of the Kenyan coast. Med Vet Entomol 1996, 10:25I-259.

47. Njau RJA, Mosha FW, Nguma JFM: Field trials of pyrethroid impregnated bednets in northern Tanzania. I.Effects in malaria transmission. Insect Sci Appl 1993, 5:575-584.

48. Bogh C, Pedersen EM, Mukoko DA, Ouma JH: Permethrinimpregnated bed net effects on resting and feeding behaviour of lymphatic filariasis vector mosquitoes in Kenya. Med Vet Entomol 1998, I 2:52-59.

49. Lines JD, Myamba J, Curtis CF: Experimental hut trials of permethrin-impregnated mosquito nets and eave curtains against malaria vectors in Tanzania. Med Vet Entomol 1987, I:37-5I.

50. Chinery WA: Effects of ecological changes on the malaria vectors Anopheles funestus and Anopheles gambiae complex mosquitoes in Accra, Ghana. J Trop Med Hyg 1984, 87(2):75-8I.

51. Sattler MA, Mtasiwa D, Kiama M, Premii Z, Tanner M, Killeen GF, Lengeler C: Habitat characterization and spatial distribution of Anopheles sp. mosquito larvae in Dar es Salaam (Tanzania) during an extended dry period. Malar / 2005, 4(I):4

52. Vanek MJ, Shoo B, Mtasiwa D, Kiama M, Lindsay SW, Fillinger U, Kannady K, Tanner M, Killeen GF: Community-based surveillance of malaria vector larval habitats: a baseline study in urban Dar es Salaam, Tanzania. BMC Public Health 2006, 6:154.

53. Keating J, Maclntyre K, Mbogo C, Githeko A, Regens JL, Swalm C, Ndenga B, Steinberg LJ, Kibe L, Githure Jl, Beier JC: A geographic sampling strategy for studying relationships between human activity and malaria vectors in urban Africa. Am J Trop Med Hyg 2003, 68(3):357-365.

54. Jacob B, Regens JL, Mbogo CM, Githeko AK, Keating J, Swalm CM, Gunter JT, Githure Jl, Beier JC: Occurrence and distribution of Anopheles (Diptera: Culicidae) larval habitats on land cover change sites in urban Kisumu and urban Malindi, Kenya. J Med Entomol 2003, 40(6):777-784.

55. Keating J, Macintyre K, Mbogo CM, Githure JI, Beier JC: Characterization of potential larval habitats for Anopheles mosquitoes in relation to urban land-use in Malindi, Kenya. Int $J$ Health Geogr 2004, 3(I):9.

56. Trape JF: Malaria and urbanization in Central Africa: the example of Brazzaville. Part I: Description of the town and previous surveys. Trans R Soc Trop Med Hyg 1987, 8I (Supplement 2): I-9.

57. Minakawa N, Mutero CM, Githure JI, Beier JC, Yan G: Spatial distribution and habitat characterization of Anopheline mosquito larvae in Western Kenya. Am J Trop Med Hyg 1999, 6I(6): $1010-1016$

58. RollBackMalariaPartnership : Scaling up insecticide treated netting programmes in Africa: a strategic framework for coordinated national action. In World Health Organization, Geneva Geneva , World Health Organization; 2005.

59. Lengeler $C$ : Insecticide-treated bed nets and curtains for preventing malaria. Cochrane Database Syst Rev 2004:CD000363.

60. Lindsay SW, Jawara M, Paine K, Pinder M, Walraven GE, Emerson PM: Changes in house design reduce exposure to malaria mosquitoes. Trop Med Int Health 2003, 8(6):512-5I7.

61. Lindsay SW, Emerson PM, Charlwood JD: Reducing malaria transmission by mosquito-proofing homes. Trends Parasitol 2002, I8(II):5I0-5I4.

62. Rozendaal JA: Vector Control. Methods for use by individuals and communities. Geneva, WHO; 1997.

63. Rowland M, Freeman T, Downey G, Hadi A, Saeed M: DEET mosquito repellent sold through social marketing provides personal protection against malaria in an area of all-night mosquito biting and partial coverage of insecticide-treated nets: a case-control study of effectiveness. Trop Med Int Health 2004, 9(3):343-350.

64. Snow RW, Peshu N, Forster D, Bomu G, Mitsanze E, Ngumbao E, Chisengwa R, Armstrong Schellenberg JRM, Hayes RJ, Newbold Cl, Marsh K: Environmental and entomological risk factors for the development of clinical malaria among children on the Kenyan coast. Trans R Soc Trop Med Hyg 1998, 92:38I-385.

65. Koram KA, Bennett S, Adiamah JH, Greenwood BM: Socio-economic risk factors for malaria in a peri-urban area of The Gambia. Trans R Soc Trop Med Hyg 1995, 89(2): I 46-I50.

66. Muirhead-Thomson RC: The significance of irritability, behaviouristic avoidance and allied phenomena in malaria eradication. Bull World Health Organ 1960, 22:721-734.

67. Muirhead-Thomson RC: The winter activities of An. gambiae at high altitudes in Southern Rhodesia. unpublished WHO working document 1960.

68. Faye O, Konate L, Gaye O, Fontenille D, Sy N, Diop A, Diagne M, Molez JF: Impact of the use of permethrin pre-impregnated mosquito nets on malaria transmission in a hyperendemic village of Senegal. Med Trop (Mars) I998, 58(4):355-360.

69. Cuzin-Ouattara N, Van den Broek AHA, Habluetzel A: Wide-scale installation of insecticide-treated curtains confers high levels of protection against malaria transmission in a hyperendemic area of Burkina Faso. Trans R Soc Trop Med Hyg 1999, 93:473-479.

70. Illboudo-Sanogo E, Cuzin-Ouattara N, Diallo DA, Cousens SN, Esposito F, Habluetzel A, Sanon S, Ouedraogo AP: Insecticidetreated materials, mosquito adaptation and mass effect: entomological observations after five years of vector control in Burkina Faso. Trans R Soc Trop Med Hyg 200I, 95(4):353-360.

7I. Takken W: Do insecticide-treated bednets have an effect on malaria vectors? Trop Med Int Health 2002, 7( I 2): 1022- 1030

72. Lindsay SW, Adiamah JH, Miller JE, Armstrong JRM: Pyrethroidtreated bednet effects on mosquitoes of the Anopheles gambiae complex. Med Vet Entomol 199I, 5:477-483.

73. Miller JE, Lindsay SW, Armstrong JRM: Experimental hut trials of bednet impregnated with synthetic pyrethroid and organophosphate insecticides for mosquito control in The Gambia. Med Vet Entomol 1991, 5:465-476.

74. Lindsay SW, Adiamah JH, Armstrong JRM: The effect of permethrin-impregnated bed nets on house entry by mosquitoes in The Gambia. Bull Entomol Res 1992, 82:49-55.

75. Lindsay SW, Snow RW: The trouble with eaves: house entry by vectors of malaria. Trans $R$ Soc Trop Med Hyg 1988, 82(4):645-646. 
76. Adiamah JH, Koram KA, Thomson MC, Lindsay SW, Todd SJ, Greenwood BM: Entomological risk factors for severe malaria in a peri-urban area of The Gambia. Ann Trop Med Parasitol 1993, 87(5):49I-500.

77. Lindsay SW, Armstrong Schellenberg JRM, Zeiler HA, Daly RJ, Salum FM, Wilkins HA: Exposure of Gambian children to Anopheles gambiae vectors in an irrigated rice production area. Med Vet Entomol 1995, 9:50-58.

78. Lindsay SW, Campbell H, Adiamah JH, Greenwood AM, Bangali JE, Greenwood BM: Malaria in a periurban area of The Gambia. Ann Trop Med Parasitol 1990, 84:553-562.

79. Braimah N, Drakeley C, Kweka E, Mosha FW, Helinski M, Pates H, Maxwell CA, Massawe T, Kenward MG, Curtis C: Tests of bednet traps (Mbita traps) for monitoring mosquito populations and time of biting in Tanzania and possible impact of prolonged ITN use. Int J Trop Insect Sci 2005, 25(3):208-2 I3

80. Oyewole IO, Awolola TS: Impact of urbanization on bionomics and distribution of malaria vectors in Lagos, southwestern Nigeria. J Vector Borne Dis 2006, 43:I73-I78.

8I. Mukabana WR, Kannady K, Kiama GM, ljumba JN, Mathenge EM, Kiche I, Nkwengulila G, Mboera L, Mtasiwa D, Yamagata Y, van Schayk I, Knols BG, Lindsay SW, Caldas de Castro M, Mshinda H, Tanner M, Fillinger U, Killeen GF: Ecologists can enable communities to implement malaria vector control in Africa. Malar J 2006, 5:9.

82. Castro MC, Singer B: Migration, Urbanization and Malaria: A Comparative Analysis of Dar es Salaam, Tanzania and Machadinho, Rondônia, Brazil. Paper prepared for Conference on African Migration in Comparative Perspective Johnnesburg, South Africa 2003.

83. Craig MH, Snow RW, le Sueur D: A climate-based distribution model of malaria transmssion in sub-Saharan Africa. Parasitol Today 1999, I5(3): 105-III.

84. Statistics NB: The 2002 population and housing census general report. 2003 [http://www.tanzania.go.tz/census/dsm.htm]

85. Killeen GF, Kihonda J, Lyimo E, Oketch FR, Kotas ME, Mathenge E, Schellenberg JA, Lengeler C, Smith TA, Drakeley CJ: Quantifying behavioural interactions between humans and mosquitoes: Evaluating the protective efficacy of insecticidal nets against malaria transmission in rural Tanzania. BMC Infect Dis 2006, 6(I): 161 .

86. Service MW: A critical review of procedures for sampling populations of adult mosquitoes. Bull Entomol Res 1977, 67:343-382.

87. Gillies MT, DeMeillon B: The Anophelinae of Africa South of the Sahara (Ethiopian zoogeographical region). Johannesburg , South African Institute for Medical Research; 1968.

88. Gillies MT, Coetzee M: A supplement to the Anophelinae of Africa South of the Sahara (Afrotropical region). Johannesburg, South African Medical Research Institute; 1987.

89. Scott JA, Brogdon WG, Collins FH: Identification of single specimens of the Anopheles gambiae complex by the polymerase chain reaction. Am J Trop Med Hyg 1993, 49:520-529.

90. Burkot TR, Williams JL, Schneider I: Identification of Plasmodium falciparum-infected mosquitoes by a double antibody enzyme-linked immunosorbent assay. Am J Trop Med Hyg 1984, 33:783-788.

91. Mukabana WR, Takken W, Knols BGJ: Host-specific cues cause differential attractiveness of Kenyan men to the African malaria vector Anopheles gambiae. Malaria J 2002, I:I7.

92. Knols BG, de Jong R, Takken W: Differential attractiveness of isolated humans to mosquitoes in Tanzania. Trans $R$ Soc Trop Med Hyg 1995, 89(6):604-606.

93. Lindsay SW, Adiamah JH, Miller JE, Pleass RJ, Armstrong JRM: Variation in the attractiveness of human subjects to malaria mosquitoes (Diptera: Culicidae) in The Gambia. J Med Entomol 1993, 30:368-373.

94. MacDonald G: The epidemiology and control of malaria. London , Oxford University Press; 1957.

95. Killeen GF, Smith TA: Exploring the contributions of bed nets, cattle, insecticides and excitorepellency to malaria control: a deterministic model of mosquito host-seeking behaviour and mortality. Trans R Soc Trop Med Hyg 2007, I 0 I(9):867-80.

96. Smith DL, McKenzie FE: Statics and dynamics of malaria infection in Anopheles mosquitoes. Malar J 2004, 3(I): I 3 .

97. Asidi AN, N'Guessan R, Koffi AA, Curtis CF, Hougard JM, Chandre F, Corbel V, Darriet F, Zaim M, Rowland MW: Experimental hut evaluation of bednets treated with an organophosphate (chlorpyrifos-methyl) or a pyrethroid (lambdacyhalothrin) alone and in combination against insecticide-resistant Anopheles gambiae and Culex quinquefasciatus mosquitoes. Malar J 2005, 4(I):25.

98. Graham K, Kayedi MH, Maxwell C, Kaur H, Rehman H, Malima R, al. Multicountry field trials comparing wash-resistance of PermaNet and conventional insecticide-treated nets against anopheline and culicine mosquitoes. Med Vet Entomol 2005 19:72-83.

99. Maclntyre K, Keating J, Sosler S, Kibe L, Mbogo CM, Githeko A, Beier JC: Examining the determinants of mosquito avoidance practcies in two Kenyan cities. Malaria J 2002, I:I4.

100. Roberts DR, Alecrim WD, Hshieh P, Grieco JP, Bangs M, Andre RG Chareonviriphap T: A probability model of vector behavior: effects of DDT repellency, irritancy, and toxicity in malaria control. J Vector Ecol 2000, 25(I):48-6I.

I0I. Kulkarni MA, Kweka E, Nyale E, Lyatuu E, Mosha FW, Chandramohan $D$, Rau ME, Drakeley C: Entomological evaluation of malaria vectors at different altitudes in Hai district, northeastern Tanzania. J Med Entomol 2006, 43(3):580-588.

102. Schellenberg JR, Abdulla S, Nathan R, Mukasa O, Marchant T], Kikumbih N, Mushi AK, Mponda H, Minja H, Mshinda H, Tanner M, Lengeler C: Effect of large-scale social marketing of insecticide-treated nets on child survival in rural Tanzania. Lancet 200I, 357(9264): | 24|-I247.

103. Abdulla S, Schellenberg JA, Nathan R, Mukasa O, Marchant T, Smith $T$, Tanner M, Lengeler C: Impact on malaria morbidity of a programme supplying insecticide treated nets in children aged under 2 years in Tanzania: community cross sectional study. BMJ 200I, 322(728I):270-273.

104. White GB: Anopheles gambiae complex and disease transmission in Africa. Trans R Soc Trop Med Hyg I 974, 68(4):279-30I.

105. Lindsay SW, Parson L, Thomas C]: Mapping the ranges and relative abundance of the two principle African malaria vectors, Anopheles gambiae sensu stricto and An. arabiensis, using climate data. Proceedings of the Royal Society of London Series B 1998 , 265(1399):847-854.

106. Gray EM, Bradley TJ: Physiology of desiccation resistance in Anopheles gambiae and Anopheles arabiensis. Am J Trop Med Hyg 2005, 73(3):553-559.

107. Charlwood JD, Pinto J, Ferrara PR, Sousa CA, Ferreira C, Gil V, Do Rosario VE: Raised houses reduce mosquito bites. Malar J 2003, 2(I):45.

108. Laganier R, Randimby FM, Rajaonarivelo V, Robert V: Is the Mbita trap a reliable tool for evaluating the density of anopheline vectors in the highlands of Madagascar? Malar J 2003, 2(I):42.

109. Wanji S, Tanke T, Atanga SN, Ajonina C, Nicholas T, Fontenille D: Anopheles species of the mount Cameroon region: biting habits, feeding behaviour and entomological inoculation rates. Trop Med Int Health 2003, 8(7):643-649.

I I0. Shililu J, Ghebremeskel T, Seulu F, Mengistu S, Fekadu H, Zerom M, Asmelash GE, Sintasath D, Mbogo C, Githure J, Brantly E, Beier JC, Novak RJ: Seasonal abundance, vector behavior, and malaria parasite transmission in Eritrea. J Am Mosq Control Assoc 2004, 20(2): I55- 164

III. Afolabi BM, Amajoh CN, Adewole TA, Salako LA: Seasonal and temporal variations in the population and biting habit of mosquitoes on the Atlantic coast of Lagos, Nigeria. Med Princ Pract 2006, I 5(3):200-208.

I I2. Lengeler C: Insecticide-treated nets for malaria control: real gains. Bull World Health Organ 2004, 82(2):84.

I 13. Hawley WA, Phillips-Howard PA, ter Kuile FO, Terlouw DJ, Vulule JM, Ombok M, Nahlen BL, Gimnig JE, Kariuki SK, Kolczak MS, Hightower AW: Community-wide effects of permethrin-treated bednets on child mortality and malaria morbidity in western Kenya. Am J Trop Med Hyg 2003, 68 (Supplement 4): I 2 I-I 27.

1 14. Le Menach A, Takala S, McKenzie FE, Perisse A, Harris A, Flahault A, Smith DL: An elaborated feeding cycle model for reductions in vectorial capacity of night-biting mosquitoes by insecticide-treated nets. Malar J 2007, 6:10.

II5. Fillinger U, Lindsay SW: Suppression of exposure to malaria vectors by an order of magnitude using microbial larvicides in rural Kenya. Trop Med Int Health 2006, I I ( I I): I 629-I642.

I I6. Killeen GF, Fillinger U, Kiche I, Gouagna LC, Knols BGJ: Eradication of Anopheles gambiae from Brazil: lessons for malaria control in Africa? Lancet Infect Dis 2002, 2:618-627. 
I17. Keiser J, Singer BH, Utzinger J: Reducing the burden of malaria in different eco-epidemiological settings with environmental management: a systematic review. Lancet Infect Dis 2005, 5(I I):695-708.

I 18. Utzinger J, Tanner M, Kammen DM, Killeen GF, Singer BH: Integrated programme is key to malaria control. Nature 2002, $419: 431$.

1 19. Utzinger J, Tozan Y, Singer BH: Efficacy and cost effectiveness of environmental management for malaria control. Trop Med Int Health 200I, 6(9):677-687.

Publish with Bio Med Central and every scientist can read your work free of charge

"BioMed Central will be the most significant development for disseminating the results of biomedical research in our lifetime." Sir Paul Nurse, Cancer Research UK

Your research papers will be:

- available free of charge to the entire biomedical community

- peer reviewed and published immediately upon acceptance

- cited in PubMed and archived on PubMed Central

- yours - you keep the copyright
BioMedcentral 